Makale Gönderim Tarihi/Received Date: 29.10.2020 - Makale Kabul Tarihi/Accepted Date: 21.12.2020

Toplum ve Kültür Araştırmaları Dergisi

Journal of Social and Cultural Studies

www.toplumvekultur.com

Y11/Year: 2020, Say1/Issue: 6, Sayfa/Page: 154-168

DOI: $10.48131 /$ jscs. 817843

\title{
ADAM ÖLDÜREN KADINLARA FARKLI BİR PERSPEKTİFTEN BAKIŞ
}

Rumeysa $A K G \ddot{U} N^{1}$

\section{Öz}

Adam öldürme suçu her ne kadar çoğunlukla erkeklerin işlediği bir suç gibi görünse de suç istatistiklerine bakıldığında az olmakla birlikte kadınların bir kısmının bu suçu işlediği görülmektedir. Adam öldürme gibi önemli bir suçun nedeni şüphesiz tek bir unsura bağlanamayacak kadar karmaşıktır. Kriminoloji ve suç sosyolojisi alanında adam öldüren kadınlar ile ilgili yapılan çalısmalarda kadınların bu suçu işleme nedenleri ile ilgili pek çok kuram ve açıklama mevcuttur. Adam öldüren kadınlar konusunda yapılan araştırmalar ve medyada yer alan haberler kadınların öldürdükleri kişilerin çoğunlukla eşler, sevgililer veya kendilerine tecavüz eden kişiler olduğunu göstermektedir. Bu durum kadınların adam öldürme suçunu büyük ölçüde birinci dereceden tanıdıklarına karşı işledikleri görüşünü desteklemektedir.

Adam öldürme suçunu işleyen kadınların öldürme eylemini gerçekleştirmeden önce çoğunlukla çocukluktan itibaren yaşamlarının şiddet, tecavüz gibi olaylarla sarmalandığı görülmektedir. Bu durumda yaşadığı travmalar sonucunda kendisine şiddet uygulayan, tecavüz eden/etmeye çalışan kişiyi öldüren kadın suçlu mudur kurban mıdır? Türk Ceza Kanununda bu sorunun cevabı birkaç istisna dışında şüphesiz açıktır. Buna karşın sosyal hizmet gibi sosyal refah ve sosyal adaleti gerçekleştirmeye çalışan bir disiplinde bu sorunun cevabı oldukça zordur.

$\mathrm{Bu}$ çalışmanın konusu adam öldüren kadınların suçlu mu yoksa kurban mı olduklarının incelenmesidir. Bu doğrultuda çalışmanın amacı sosyal hizmet disiplini üzerinden adam öldüren kadınlara farklı bir bakış açısı geliştirmektir. Çalışmada kadınların adam öldürme nedenlerini açıklayan kuramlar, kadınları adam öldürmeye götüren nedenler ve sosyal hizmet odağında adam öldüren kadınlar konuları ele alınarak kadınların suçlu mu kurban mı olduklarına ilişkin sorunun cevabi aranacaktır.

Anahtar Kelimeler: Adam Öldüren Kadın, Adam Öldüren Kadın Kuramları, Kurban, Suç

${ }^{1}$ Dr.Öğr.Üyesi., Kırıkkale Üniv.Sağlık Bilimleri Fakültesi Sosyal Hizmet Bölümü, rumeysaakgun@gmail.com, ORCID: 0000-00034226-2191 


\title{
A DIFFERENT PERSPECTIVE ON WOMEN WHO MURDERED MEN
}

\begin{abstract}
Although homicide is seen as a crime mostly committed by men, it is seen that some of the women committed this crime, although it is rare when looking at the crime statistics. The cause of an important crime like murder is undoubtedly too complex to be attributed to a single factor. There are many theories and explanations about the reasons why women commit this crime in studies about women who kill people in the field of criminology and crime sociology. Research on women who kill people and news in the media show that the people killed by women are mostly spouses, lovers or people who raped them. This situation supports the view that women mostly committed murder against their first-degree acquaintances.

It is observed that the lives of women who have committed murder have been wrapped up with incidents such as violence and rape, since childhood, before committing the act of murder. In this case, as a result of the traumas she experienced, the woman who inflicted violence on her, raped / killed the person who tried to rape her, is she a criminal or a victim? The answer to this question in the Turkish Penal Code is undoubtedly clear, with a few exceptions. However, the answer to this question is quite difficult in a discipline that tries to realize social welfare and social justice, such as social work.

The subject of this study is to examine whether women who killed men were criminals or victims. In this direction, the aim of the study is to develop a different perspective on women who kill people through social work discipline. In the study, the theories explaining the reasons for female homicide, the reasons leading women to murder, and the issues of women who kill people in the focus of social work will be discussed, and the answer to the question about whether women are criminals or victims will be sought.
\end{abstract}

Keywords: Crime, Female Homicide, Theory of Female Homicide, Victim

\section{Giriş}

Katil kelimesini işittiğimizde karanlık kişiler, yeni kurbanlarını bekleyen caniler aklımıza gelir. Çoğunlukla da bu suçu bir erkeğin işleyebileceği düşünülür. Cinayet şüphelisi ya da tutuklanan kişinin kadın olduğunu öğrendiğimizde şok oluruz (Jensen, 2001: s. 1). Kadın suçluluğu kavramı 20. yy’a kadar çok fazla göz önüne alınan bir kavram değildi. Kadın suçluluğunun görünürlüğünün bu kadar geç gündeme gelmesinin nedeni kadınların tarihin her döneminde erkeklere göre daha az suç işlemesinden kaynaklandığı düşünülmektedir. Özellikle ikinci dalga feminizm hareketleriyle birlikte feminist kriminolojide cinsiyet ve suç kavramlarına odaklanıldı (Lind, 2006).

2008-2017 yılları arasında Avrupa Birliği ülkelerinde kadın ve erkek hükümlü sayısına bakıldığında erkek hükümlü sayısının kadın hükümlü sayısından 100.000 fazla olduğu; en fazla kadın hükümlü sayısının ise Letonya'da olduğu görülmüştür (Eurostat, 2020). Bu sonuçtan yola çıkarak suç türleri açısından bakıldığında adam öldürme oranlarında kadınların erkeklerden daha az bu suçu işledikleri söylenebilir. Adam öldürme suçunu işleyen kadınların suçlu mu kurban mı 
oldukları konusunu tartışmaya geçmeden önce kadınların neden adam öldürdükleri incelenmekte yarar vardir.

\section{Kadınlar Neden Adam Öldürür?}

Kadınların neden adam öldürme suçunu işlediklerini sorgulamak şüphesiz adam öldüren kadınlar suçlu mu kurban mi sorusundan daha kolay cevaplanacak bir sorudur. Erkeklerin kadınları öldürme nedenlerine bakıldığında ekonomik sebepler, kadınların boşanmak istemesi, barışma isteğini reddetmesi, arkadaşlık isteğini kabul etmemesi gibi sebepler sıralanabilir (Kadın Cinayetlerini Durduracagiz Platformu, 2019). Kadınların adam öldürme nedenlerine bakıldığında ise, bu durumla ilgili iki yaklaşım söz konusudur. Bu yaklaşımlardan ilki kadınların adam öldürmelerini açıklayan kuramlardır. İkinci yaklaşım ise Akgün (2019)'ün kadınları adam öldürme suçuna götüren patikalar çalışmasından yola çıkarak kadınları adam öldürme suçunu işlemelerine neden olan etmenler incelenecektir.

\subsection{Adam Öldüren Kadınlar ile İlgili Kuramlar}

Adam öldürme ile ilgili kuramlara bakıldığında, genellikle kadınları sadece sayısal verilerde ele aldıkları görülmektedir. Geleneksel dönem adam öldürme kuramlarında, cinsiyet değişkenini dikkate almadan kadın ve erkeklerin cinayet işleme motivasyonları aynı nedenlere bağlanmaktadır. Sadece yoksunluk kuramaları, alt kültür kuramları kadınları ve yaşamlarını dikkate almıştır (Jensen, 2001: s. 23).

Kadın suçluluğunun erkek suçluluğundan ayrı değerlendirilmeye başlanması feminist hareketler ile önem kazanmıştır. Kadınların geleneksel kadın rollerinden duydukları memnuniyetsizlikten dolayı seslerini yükseltmeye başlamasıyla ortaya çıkan kadın hareketleri ile birlikte feminist kuramlar ortaya çıkmıştır (Corey, 2008: s. 374). Kadınların farklı yönlerine (Liberal, Kültürel, Marksist, Sosyalist) odaklanan feminist kuramlara 1970'li yıllardaki ikinci dalga feminist hareketinin eklenmesi sonucu Feminist Kriminoloji kavramı ortaya çıkmıstır (Chesnesy Lind, 2006; Burgess-Proctor, 2009). Böylece suç işleyen kadınların durumu artık erkek suçlulardan bağımsız olarak değerlendirilmeye başlanmıştır. İlk dönemlerde kadınların neden suç işlediği üzerine çalışan feminist kriminologlar, daha sonraki yıllarda kadınların erkeklere göre neden daha az suç işlediği üzerinde çalışmalar yapmıştır (Dolu, 2011: s. 447).

Kadınlar her dönemde erkeklere göre daha az suç işlemiştir. Suç özelinde bakıldığında ise adam öldürme suçunu işleyen kadın sayısı Dünya'da olduğu kadar Türkiye'de de daha azdır. Bu 
durumu açıklayan pek çok yaklaşım olmakla birlikte kadınların adam öldürme suçunu işlemesinde patriarkal yapıya sahip toplumların daha çok etkili olduğu düşünülmektedir. Bununla birlikte özellikle suç sosyolojisi alanında kadınların adam öldürme nedenlerini açıklayan kuramlar bulunmaktadır. Bu kuramların bir kısmı sonraki bölümde verilmiştir.

\subsection{1. Şiddet Alt Kültürü Kuramı}

Şiddet alt kültürü kuramı, adam öldürmeyi ve şiddetin davranış üzerindeki etkisini açıklayan sosyolojik kuramlardan en yaygın olanıdır (Wallace, 1986). Şiddet alt kültürü, aile kültüründeki değerleri ve tutumları paylaşır. Kişilerin şiddet davranışını alt kültür olarak benimsediklerini anlamak için o alt kültürdeki değerlere ve tutumlara bakmak gerekir. Buna göre bir alt kültürde normlar, tutumlar ve değerlerde şiddet davranışına eğilim fazla ise o alt kültür üyeleri diğerlerinden daha fazla şiddet göstermektedir (Ball Rokeach, 1973). Bununla birlikte değerlere ve geleneklere daha fazla bağlı olan kesimlerde şiddetin daha fazla ve kuralların daha sert olduğu söylenebilir. Halkın aşiretlere ayrıllığı ve törelerle yönetilen Doğu Anadolu, Güneydoğu Anadolu gibi bölgelerde kadına yönelik şiddetin ve kadın cinayetlerinin daha fazla olması bu duruma örnek gösterilebilir (Akgün, 2017).

\subsubsection{Sosyal Rol Kuram1}

Sosyal rol kuramı, kadınlar ile erkekler arasındaki davranışsal farklılıkların cinsiyet kalıp yargıları ve sosyal rollerle açıklanabileceğini savunur. Bu roller, toplum tarafindan tanımlanan, bir sosyal kategorideki bireylerin hepsinden beklenen, öğrenilmiş tepkilerdir (Dökmen, 2015: s. 82). Bu kalıplar, kadın ve erkeğin toplum içindeki rollerini belirler. Toplumdan topluma değissmekle birlikte, genel anlamda, toplumların kadınlara atfettiği roller ve erkeklere atfettiği roller birbirine benzer özellik taşır. Kadınlar her ne kadar bazı toplumlarda daha fazla evin dışında çalısssa da özellikle eril hâkimiyetin fazla olduğu toplumlarda kadının temel görevi, evin düzenini ve çocukların bakımını sağlamaktır. Erkeklerin görevi ise, dışarıda evin ihtiyacı olan parayı temin etmektir. Böyle bir toplumsal düzenin olduğu bir ortamda kadının suç işlemesi elbette düşünülemez. Çünkü şiddet içerikli suçlar kadınların cinsiyet rollerinden beklenen bir suç türü değildir (James, 2000). Kadın suç işlediğinde ise (özellikle adam öldürme gibi) bu durum onun cinsiyetine özgü davranış kalıplarının dışına çıktığı anlamına gelmektedir (Akgün, 2017). 


\subsubsection{Kendini Savunma Modeli}

Özellikle ataerkilliğin hâkim olduğu toplumlara bakıldığında kadınların gördüğü şiddetin göz ardı edildiği, normalleştirildiği görülmüştür. Kadınlar yaşadıkları şiddetin sonucunda da büyük oranda kendini savunmak amacıyla adam öldürme suçunu işleyebilmektedir. Buna karşın özellikle kadınlar erkekler kadar kendilerini savunamamakta (McMahon, 2013), yaşadıkları şiddeti ve istismarı mahkemede anlatamamaktadır. Adam öldürme suçunu işleyen kadınlara bakıldığında; çoğunlukla kötü muamele gören ya da dayak yiyen kadınlarda aniden görülen şiddetli bir tepki sonucu ortaya çıkmakta ve önceden planlanmış bir nitelik taşımamaktadır (İçli ve ark., 1995). Kadınların kendini savunmak amacıyla adam öldürme suçunu işledikleri görüşü, 1987 yllinda Browne tarafından kendini savunma modeli olarak ortaya çıkmışır. Bu görüşe göre; kadınlar eğer cinayet işliyorlar ise, genelde evlilik ilişkilerinde yaşadıkları şiddete karşı kendilerini korumak içindir (Merlo ve Pollok, 2006).

\subsubsection{Aile İçi Şiddet ve Hırpalanmış Kadın Sendromu}

Hırpalanmış kadın, bir kadının sürekli olarak farklı şekillerde fiziksel şiddete uğramasıdır (Browne, 1987). Bu yaklaşım 1984'de Lenore Walker tarafında geliştirilmiş ve 1979'da hırpalanma döngüsü olarak adlandırılmıştır (Ogle ve Jacobs, 2002). Walker, 1986 y1lında istismarcılarına ciddi zarar veren veya öldüren 96 hırpalanmış kadınla çalışmışır. Walker, mahkemelerde 33 vaka ile hırpalanmış kadını sendromunu kanıtlamış ve 32 vakada ceza aşamasına gelmiştir (O'Donovan, 1991). Walker, 1970’lerin başında hırpalanmış kadın sendromu konusunda çalışmalarını sürdürürken hırpalanan kadınların; yoksul, eğitimsiz, kendilerine ve çocuklarına destek olabilecek bir işten yoksun ve toplum içindeki haklarından mahrum olduklarını saptamıştır (Walker, 2000). Bu kurama göre, hırpalanan mağdurlar psikolojik problemler sonucunda öğrenilmiş çaresizlik yaşamaktadırlar. Bunun sonucunda da doğru ve yanlışı birbirinden ayıramamakta ve beklenmedik olumsuz davranışları gerçekleştirmektedirler (Ogle ve Jacobs, 2002). Hırpalanmış kadın sendromu, kadınların istismar döngüsünün onları psikolojik olarak nasıl etkilediğini ve bunun sonucunda cinayete sebep olduğunu açıklamak üzere Amerika Birleşik Devletlerinde tanımlanmıştır (England, 2007). İngiltere ve Galler'de ise, mahkemelerde jüri istismara uğrayan kadınlar adam öldürdüğünde, bunu adam öldürme suçu olarak ele almamaktadır (Kochan, 1989). 


\subsubsection{Postpartum Depresyon, Psikoz ve Psikolojik Rahatsızlıklar}

Bu kurama göre kadınlar hamilelik ve doğumu takip eden zamanlarda hormonal ve kimyasal değişiklikler sonucu doğum sonrası depresyona maruz kalabilir. Yaşanan bu depresyon sonucunda, bazı kadınlarda bu psikolojik durumların geliştiği ve bunun psikozu oluşturduğu, sonuçta da kadınların gerçeklik algılarını kaybederek zararlı davranışlar içine girdiği veya gerçekte ne yaptığını bilmeyerek çocuklarını öldürdükleri görülmektedir (Ogle ve Jacobs, 2002; Friedman ve Resnick, 2007). Resnik (1969)'in çocuk cinayetleri ile ilgili yaptı̆̆1 131 vaka çalışmasında, kadınların cinayet işleme nedeninin fedakârlık, akut psikotik, istenmeyen çocuk, kazara ve eşten intikam almak olduğu görülmüştür (Resnick, 1969).

Doğum sonrası dönemde, aileye yeni bireyin katılımıyla birlikte özellikle annenin sorumlulukları da artmaktadır. Doğum sonrası dönemde anne depresyon yaşamışsa ve çevresinde kendisine destek olabilecek kişi yoksa yaşadığı bunalımın ve psikolojik sorunların kaynağını çocuğu olarak görebilir ve çocuğuna zarar verebilir. Bu zararın boyutları annenin içinde bulunduğu psikolojik duruma göre değişebilir. Bazen anne bebeğe sadece şiddet uygularken bazen de çocuğunu öldürebilir. Buna ek olarak özellikle evlilik dışı birlikteliklerde anne adayı gençse ve bebeğin babası çocuğu kabul etmemişse anne depresyona girebilmekte ve bu durumda bazen sadece çocuğunu öldürürken bazen de hem kendisini hem de çocuğu ölüme terk etmektedir (Akgün, 2019: s.43).

Bennett vd., (2012) adam öldürme suçu işleyen kadınlarla yapılan araştırmada 55 kişinin 11'inde psikotik rahatsızlı olduğunu, ve 9'una cezaevine girmeden önce şizofreni tanısı konulduğunu ortaya koymuştur. Buna ek olarak çalışmalarda, cinayet suçu işleyen kadınlardaki psikozun diğerlerine göre ortalama 21 kat, şizofreni hastasının ise ortalama 43 kat daha fazla olduğu saptanmıştır.

Genel olarak bakıldığında çocuk öldüren faillerin bu suçu işlemelerinin beş ana nedeni vardır. Bunlar; a) Bir anne çocuğunu sevgisinden öldürür; ölümün çocuğun yararına olduğuna inanır (örneğin intihara meyilli bir anne, annesiz çocuğunu tahammül edilemez bir dünyayla yüzleşmek için terk etmek istemeyebilir veya psikotik bir anne, çocuğunu ölümden daha kötü bir kaderden kurtardığına inanabilir) ; b) akut psikotik bir cinayet olayında, psikotik ya da ruh sağlığ1 yerinde olmayan bir anne çocuğunu anlaşllır bir sebep olmadan öldürür (örneğin, bir anne öldürmek için emir aldığını söyleyebilir); c) ölümcül kötü muamele olayları meydana geldiğinde, ölüm genellikle beklenen sonuç değildir; kümülatif çocuk istismarı, ihmali veya Munchausen sendromundan (özellikle annelerin dikkat çekmek, çevresindeki bireyilerin veya sağlık 
personelinin ilgisini çekmek için yapay yollarla kendisine çoğunlukla da çocuğa zarar vermesi, çocuğuna verdiği çeşitli maddeler ile çocuğunun hastalanmasına neden olması) kaynaklanır; d) anne çocuğunu istemiyor olabilir, bir anne çocuğunu bir engel olarak düşünür; e) En nadir görülen eş intikam cinayeti, bir annenin özellikle çocuğun babasına duygusal olarak zarar vermek için çocuğunu öldürmesi durumunda ortaya çıkar (Hatters Frıedman ve Resnick, 2007).

\subsubsection{Cinsiyete Dayalı Patikalar Yaklaşımı}

Daly (1992) tarafindan Gendered Pathway olarak adlandirılan ve Akgün (2017) tarafindan Cinsiyete Dayalı Patikalar yaklaşımı olarak Türkçe'ye çevrilen bu kuram; kadınların yaşadıkları çeşitli olayların ve yaşam koşullarının onları suça ittiğini belirtmektedir. Kadınlar, kadın oldukları için konumlandırıldıkları ikinci sınıf statüleri onların yaşamlarını oldukça etkilemektedir. Madde bağımlılığı, fiziksel ve cinsel istismar, erkeklerle olan baskıcı ilişkiler, ekonomik bağımsızlığın olmayışı onların ilk deneyimlerini biçimlendirmekte ve cezaevine girmelerine neden olabilmektedir. Buna ek olarak; 1rkçılık, cinsiyetçi tutumlar, düşük ekonomik imkânlar ve kadın statüsünün değersizliği kadınları pasivize etmekte ve rollerini sınırlandırmaktadır. Bu durumun sonucu, kadınların yaşadıkları olaylar onları suça götürebilmektedir (Owen, 1998: s.40-41 Akt: Akgün, 2019:s.53).

Daly (1992) kadınları suça götüren faktörleri dikkat aldığında kadınları‡ zarar gören ve zarar veren kadınlar, hırpalanmış kadınlar, hayat kadınları, maddeyle ilişkili kadınlar ve diğerleri olarak beş ayrı kategoride incelemiştir. Buna göre kadınlar yaşadıkları bazı olumsuzlar sonucu şiddete yönelmekte ve cezaevine girmektedir.

Cezaevlerine bakıldığında hem içinde bulunduğu koşulları ile hem de bireyin çevresinden, sevdiklerinden izole etmesi nedeniyle kişilerin içinde bulunmak istemeyeceği bir yap1 olduğu görülmektedir Akgün (2019: s.111) 'ün yaptı̆̆1 araştırmada adam öldürme suçundan cezaevine giren kadınlar cezaevini "üstü açık bir mezar", "ucu bucağı olmayan yer” ve "diri diri gömülmek" gibi ifadelerle tanımlamıştır. Bu kadar korkunç ve istenmeyen bir yer olarak tanımlanan cezaevine daha çok güç ve cesaret isteyen bir suçu işleyip girmek kadınların isteyeyeceği bir durum değildir. Tüm bu bilgiler ışığında kadınlanı adam öldürme suçunu işlemelerine neden olan zorlayıcı etmenlerin olduğu söylenebilir. 


\section{Kadınları Adam Öldürmeye Götüren Patikalar}

Kadınların toplum içindeki yapılanmalarına bakıldığında, özellikle ataerkil toplumlarda her zaman ikincil planda oldukları görülmektedir. Bu durum kadınların yaşamının pek çok alanında sorunlarla karşılaşmalarına neden olmaktadır. Küçüklükten itibaren yetiştikleri ataerkil kalıplar onları daha çok evin işlerine yardımcı olan, dışarıya çok fazla çıkılmasına izin verilmeyen, anneye yardımcı olan, eğitim olanaklarından yeterince yararlanamayan, ne kadar şiddet görürse görsün bu duruma başkaldıramayan, "uygun bir eş bulunduğunda kendisine sorulmadan evlendirilebilen" ve her zaman adının baba, abi, koca gibi bir erkekten sonra gelen kişiler olarak yetişmelerine neden olmaktadır. Kadınlar evlendiklerinde de içinde bulundukları durum çok değişmemektedir. Bu kez şiddet uygulayan baba veya abi yerine eşleri olmaktadır. Kadınlara yine hiçbir konuda söz hakkı verilmemektedir. Kadının temel görevi eşine itaat etmek, eşinin ailesini mutlu etmek ve çocuklarına-evine bakmak olarak görülmektedir. Bunun aksi bir durum olduğunda, ya da kadının terbiye edilmesi gerektiği düşünüldüğünde kadın yine şiddetle karşılaşmaktadır. Şiddetin son noktasında ya erkek kadını öldürmekte veya kadın çoğunlukla kendisini savunmak adına erkeği öldürmektedir. Bunların dışında kadınlar yaşadıkları şiddetin sonucu boşanabilmektedir. Fakat boşanmaların bir kısmı da erkeklerin boşanmayı kabullenemeyip boşandıkları eşlerini öldürmeleri ile sonuçlanabilmektedir. Şiddet döngüsü kırılmadığı sürece yoksulluk döngüsünün sürekli kendisini tekrar etmesi gibi şiddet döngüsü de taraflardan birisi ölene kadar veya boşanana kadar süreç devam edecektir.

Adam öldürme suçunun psikolojik, psikopatolojik, sosyal ve gelişimsel bileşenleri bulunmaktadır (Botelho ve Abrunhosa Gonçalves, 2016). Dolayısıyla yukarıda bahsedilen şiddet döngüsü elbette başlı başına kadınların adam öldürmesinin nedeni değildir. Kadınların adam öldürmesinin altında pek çok neden bulunmaktadır. Örneğin; tacize veya tecavüze uğramak, göçün getirdiği psikososyal sorunlar, madde kullanımı, çevre koşulları ve maddi yoksunluklar kadınları adam öldürmeye götüren sebepler arasında sayılabilir. Bu sebepler dışında Akgün (2019)'ün adam öldüren kadınları suça götüren nedenlerle ilgili yaptığı çalışmasında kadınları adam öldürmeye götüren dört neden bulmuştur. Bunlar; doğuştan gelen suç: kız çocuğu olmak, anlatılamayan trajedi:taciz ve tecavüz, ataerkilliğin evlenmedeki yansımaları:baskıdan kaçış, zorla ve küçük yaşta evlendirilme ve toplumsal cinsiyete dayalı şiddet ve kabullenilmiş ataerkilliktir. Yapılan bu araştırmada adam öldürme suçundan cezaevine giren kadınların çoğunun küçük yaştan itibaren sevgisiz bir ortamda büyükdükleri, kız çocuğu oldukları için eğitim ve miras haklarından yararlandırlmadığı görülmüştür. Bu duruma ek olarak kızların önemli bir kısmı küçük yaştan itibaren şiddet görmüştür. Araştırmada kadınların adam öldürme sebeplerinden birisi de 
yaşadıkları taciz/ tecavüz olaylarıdır. Kadınların bir kısmı küçük yaştan itibaren yaşamlarının çeşitli döneminde tacize/tecavüze uğramıştır. Bir kısmı da yetişkinlik döneminde tecavüze uğradığını belirtmiştir. Yaşadıkları bu tecavüz kadınları adam öldürme suçunu işlemelerinde etkili olmuştur. Kadınları bu suçu işlemelerindeki en önemli faktörlerden birisi şüphesiz ataerkil yapıdır. Kadınların bir kısmı yaşadığı taciz ve şiddetten kaçmak adına kaçarak evlenmeyi seçmiş fakat evlendiğinde de şiddetle karşılaşmıştır. Kadınların bir kısmı ise çocuk yaşta istemedikleri kişiler ile evlendirilmiştir. Evlendiklerinde ise çoğunlukla kendi ailelerinde yaşadıkları şiddet ve diğer olumsuzluklari evlendikleri kişilerle de yaşamışlardır. Üstelik bazı kadınların evlendikleri kişiler kadınları başka erkeklerle birlikte olmaya zorlamıştır. Kadınların bir kısmı yaşadığı şiddeti kabullenirken bir kısmı da bu şiddetten kurtuluş yolu ararken öldürme eylemini gerçekleştirilmiştir.

Yukarıdaki araştırmanın bilgilerinden yola çıkarak kadınların adam öldürme suçunu işleme nedenleri incelendiğinde kadınların bu suçu işlemeye itildiği görülmektedir. Kadınlar çoğunlukla da eşlerini, sevgililerini ve aile üyelerinden birini veya kendisine tecavüz eden kişiyi öldürmektedir (Kurshan,1995). Dolayısıyla yukarıdaki sebepler her ne kadar kadınları adam öldürmeye götüren sebeplerden sayılsa dahi çoğunlukla kadınları bu suçu işlemesinin patriarkal yapıdan kaynaklandığı görülmektedir. Kadınların hayatına giren erkekler (baba, abi, eş, sevgili...) kadınların adam öldürme suçunu işlemelerinde önemli bir faktör olmaktadır.

Çocuk öldürme suçundan cezaevine giren kadınların yaşamlarına bakıldığında da şiddet gördüğü için veya tecavüze uğradığı için adam öldüren kadınların yaşamları ile benzer yaşamların olduğu görülmüştür. Elbette bir çocuğu öldürmek bir yetişkini öldürmekten çok daha ciddi sorumluluk isteyen bir suçtur. Fakat bu suçtan gelen kadınlara bakıldığında da yine evlilik dışı birliktelik sonucu oluşan çocuğunu öldürme, eşinden şiddet görmesi sonucu bunu çocuğuna yansıtma gibi ataerkil baskının kadınları çocukları öldürmeye ittiği görülmüştür. Normal şartlarda bir kadının annelik içgüdüsü ile bir çocuğu öldürmesi düşünülemez. Akgün (2017)'ün yaptığ1 çalışmada da çocuk öldürme suçundan cezaevine giren kadınların yaşamlarının normal olmadığı, bir kısmının psikolojik ilaçlar kullandıkları ve ruh sağlıklarının yerinde olmadığı görülmüştür. Dolayısı ile yapılan araştırmalar ve cezaevinde kadınlarla yapılan görüşmeler sonucundan yola çıkarak aslında kadınların ataerkil yapının bir kurbanı olduğu söylenebilir. Eril zihniyet her daim ezmek adına kadınları kullandığı, kadınların da gerek kendilerini savunmak, gerekse yaşadıkları travmaların etkisi sonucu öldürme eylemini gerçekleştirdikleri söylenebilir. Peki bu kada travmatik olay yaşayan, zaman zaman yaşamına kast edilen kadın suçlu mu kurban mı? 


\section{Sosyal Hizmet Bakış Açısıyla Adam Öldüren Kadın Suçlu Mu Kurban Mı?}

Patriarkal toplumlar kadınlara yaşam koşulları içinde özgürlük tanımamaktadır. Kadınların evlendikten sonra boşanmalarına, ayrı bir dünya kurmalarına izin vermemektedir. Kadınların kendi ayakları üzerinde durmasına başta kendi ailesi olmak üzere eşi, akrabaları kısacası içinde bulunduğu toplum karşı çıkmaktadır. Kadınların bir kısmı da boşandıklarında çevrelerinin tepkisinden çekindikleri için ya da ekonomik durumları kendi yaşamlarını idame etmelerine yeterli olmadığı için boşanamamaktadır. Kadın yaşadığı şiddeti ilgili mercilere ilettiğinde de kimi zaman şikâyetleri yine eril zihniyetin çarklarına takılmakta ve kocası, sevgilisi, evlenmek istemediği kişi, babası tarafindan öldürülmektedir. Kadınlar bazen de katilinin elinden kurtularak onu öldürmektedir. Bu noktada kadın şiddete boyun eğip ömrünün sonuna kadar şiddetçisinin insafinı mı beklemeli? Yoksa dayanamadığı bir noktada şiddetçisine şiddet gösterip onu öldürdükten sonra zaten kötü olan hayatına çocuklarından ayrı cezaevinde mi devam etmeli? Sorusu gelmektedir.

Türk Ceza Kanununa göre bu sorunun cevabı oldukça açıktır. Türk Ceza Kanununda bir kişiyi kasten öldürme ile ilgili hükümler TCK'nın 81. ve 83. maddeleri arasında düzenlenmiştir. Buna göre bir kişiyi kasten öldürmenin cezası müebbet hapis cezasıdır (TCK, 2004: s. 8987). Bu duruma ek olarak hafifletici sebepler göz önünde bulundurulduğunda kısaca kişinin neden bu suçu işlediği dikkate alındığında TCK kapsamında kişiye iyi hal indirimi veya ağırlaştırılmış hapis cezası verilir. Dolayısıyla eğer kadın kendisine şiddet uygulayan kişiyi öldürüyorsa (son dönemde meydana gelen bir kaç istisna karar dışında) hapis cezası almakta, eğer öldürme biçimine canavarca ve vahşi hislerle gibi bir durum eklenirse ağırlaştırılmış hapis cezası almaktadır. Görüldügü üzere temelde işlenen suçun cezası kanun kapsamında bellidir. Ceza kanunu sadece suçun sonucu ile ilgilenir buna karşın, psikoloji ve sosyoloji gibi sosyal billim alanları kişilerin bu suçu işleme nedenlerini psikolojik ve sosyolojik açılardan açıklamaya çalışmaktadır.

Çalışma alanları; yoksullar, madde bağımlıları, yaşlılar, korunmaya ihtiyacı olan çocuklar, suç işleyen çocuklar ve yetişkinler gibi dezavantajlı bireylerin sorunları ile ilgilenen sosyal adaleti ve sosyal refahı sağlamaya çalışan bu kapsamda politikalar geliştirilmesine destek olan sosyal hizmet mesleği ise çevresi içinde birey yaklaşımından yola çıkarak, suç işleyen bireyi çevresi ile birlikte ele almaktadır. Sosyal hizmetin odak noktası hem birey hem de bireyin içinde bulunduğu çevresidir. Dolayısıyla adam öldüren kadınlara sosyal hizmet perspektifinden bakıldığında adam öldüren kadınların suçlu mu kurban mı olduklarının sorusunun cevabı ceza kanunun aksini söylemektedir. Üstelik amacı insan hakları ve sosyal adaleti sağlamaya çalışan bir mesleğin de adam öldüren kadınları cani, canavar, suçlu olarak görmesi düşünülemez. 
Elbeltte sosyal hizmet mesleği bir kişinin hangi sebepten olursa olsun öldürülmesine karş1 çıkmaktadır. Buna karşın kadınları adam öldürme suçuna götüren patikalar düşünüldüğünde; yaşamı boyunca şiddet, yoksulluk, taciz ve tecavüz gibi travmatik olayların kurbanı olan kadın kendisine şiddet uygulayan kişiyi öldürdügünde kanunlar çerçevesinde suçludur ama yaşamı ve hayatı göz önüne alındığında ise kurbandır. Sosyal hizmet kadının bu kurbanlaştırılma durumunu odak noktası olarak almaktadır. Patriyarkal baskı, kadını çeşitli rollere hapsederek bireyselliğini ortadan kaldıran toplumsallık, sürekli bir başkasına rağmen toplumsal yaşamda görünürlük kazanma mücadelesi kadınları kurbanlara çeviren bir döngü olarak önümüzde durmaktadır. Sosyal hizmet mesleği bu döngünün kadını götürdüğü yerdeki sonuçlardan yalnızca birisi olan suça değil kurbanlaştırılma sürecindeki unsurlara ve elementlere yoğunlaşmaktadır. Kadın cezaevine girdiğinde sorunlarının çözülmesinde kendisine destek olunan, güçlendirilmesi gereken bir müracaatçıdır. Burada kadınlar ile yapılan bireysel görüşmeler, grup çalışmaları ve meslek edindirmeye yönelik kurslar ve özellikle büyük cezaevlerinde kadınlara sağlanan çalışma olanağı ile kadınlar yaşamlarına sahip çıkmayı, kendi hayatları üzerinde söz sahibi olmayı öğrenmeye çalışmaktadır.

\section{Sonuç Yerine}

Tarihte ilk insanlardan bu yana adam öldürme suçunun işlendiği düşünülürse insanlık yaşadıkça da çeşitli sebeplerden bu suçu hem erkekler hem de kadınlar tarafından işlenen bir suç olmaya devam edeceği söylenebilir. Öldürme eylemini gerçekleştiren kişi kadınsa öldürme eylemini gerçekleştirmeden önce yaşamında fiziksel, psikolojik şiddet, taciz ve tecavüz gibi bireyin ruh ve beden sağlığını bozan eylemlerin olup olmadığı dikkate alınması gerekmektedir. Bununla birlikte, kadın faillerinin veya mağdurlarının değerlendirilmesi sırasında erkeğin öldürdüğünde namusunu koruduğu kadın öldürdüğ̈̈nde ise yine suçlu olduğu bir zihniyetin ortadan kalkmas1 gerekmektedir. Özellikle ataerkil toplumlarda kadın her türlü suçlu olmakta; öldürdüğünde katil, öldügünde ise "kim bilir eşinin namusunu lekeleyecek ne yaptı?" anlayışı yine suçlanmaktadır. Yaşanan travmalara, tacizlere, şiddetlere karşı kadına ya ölmek ya da öldürülmek olarak ikisi birbirinden kötü seçenekler sunulmaktadır. Çevresinde kendisine sosyal destek bulamayan kadın ise çoğunlukla öldürülmekte veya bazı durumlarda da katilinin elinden kurutlup öldürmektedir. Bu durumda kadının suçlu değil kurban olduğu söylenebilir.

Kadınların öldürmemesi ve/veya ölmemesi için daha adil, insancıl bir dünyada yaşaması ve birey düzeyinden toplum düzeyine pek çok alınacak önlemle birlikte yapılacak çalışma 
mevcuttur. Bunun başında ataerkil düzenin ortadan kalkması ve kadınlara erkeklerle eşit firsatlar verilmesi gelmektedir. Ataerkil yapının ortadan kaldırılmasına ek olarak;

Kadınların yaşadıkları şiddetle mücadeleyi kazanmalarını sağlayacak ve şiddetin bir sonraki nesilde devam etmesini önleyecek en önemli etmen kız çocuklarının eğitim almalarını sağlamalarıdır. Bu konuda annelerin de kızlarının eğitim almalarını sağlamaları, erkeklerin eşlerine, sevgililiklerine, çocuklarına şiddet göstermelerini engellemek için gerek aile hayatında gerekse toplum içinde düzenlemeler yapılması, toplumsal cinsiyet eşitliği konusunda ilkokuldan itibaren özellikle erkek çocuklarına bilinçlendirici eğitimlerin verilmesi, kadınlara uygulanan şiddetin ve yaşamlarındaki erkek egemen yapılanmanın ortadan kalkması için toplum bilincinin oluşması oldukça önemlidir. Bu duruma ek olarak; şiddet gören kadınlara yönelik daha koruyucu hizmetlerin verilmesi, şiddeti Önleme ve İzleme Merkezleri (ŞÖNIM)'nin yaygınlaştırlması, şiddet gören kadınların barındığı kadın konukevlerinin yaygınlaştırılması ve daha aktif olarak çalışması, kadınlara meslek edindirmeye yönelik kursların oluşturulması, özellikle adam öldürme suçundan ceza alan kadınlara tahliye olduktan sonra hem psikososyal olarak hem de ekonomik olarak destek olunması, tahliye olmuş kadınları destekleyecek derneklerin kurulması, özellikle televizyon dizilerinde kadına ve çocuğa yönelik şiddeti özendiren programların kaldırılması, kadına şiddet uygulayan veya taciz,tecavüz eden erkeklere daha sert yaptırımların olması ve Türkiye'nin de ilk imzalayan ülkeler arasında olduğu kadına yönelik şiddetle mücadele konusunda hazırlanan İstanbul Sözleşmesinin daha etkili uygulanması önerilmektedir.

\section{Kaynakça}

Akgün, R. (2017). Adam Öldüren Kadınları Suça Götüren Nedenler ve Cezaevi Sürecinin İncelenmesi. Ankara: Ankara Üniversitesi Sağlık Bilimleri Enstitüsü Doktora Tezi.

Akgün, R. (2019). Adam Öldüren Kadinlar. Ankara: Nika Yayınevi.

Ball Rokeach SJ (1973). Values and Violence: A Test of The Subculture of Violence Thesis. American Sociological Review, 38(6):736-749.

Bennett, D., Ogloff, J., Mullen, P., \& Thomas, S. (2012). A Study of Psychotic Disorders Among Female Homicide Offenders. Crime and Law, 231-243.

Bourget, D., \& Bradford, J. (1990). Homicidal Parents. Can J Psychiatry, 35(3), 233-238. https://doi.org/10.1177\%2F070674379003500306 
Botelho, M., \& Gonçalves R.A. (2016). Why Do People Kill? A Critical Review Of The Literature on Factors Associated with Homicide. Aggression and Violent Behavior, 26: 9-15. https://doi org/ 10.1016/j.avb.2015.11.001

Browne, A. (1987). When Women Kill. New York: The Free Press.

Burgess Proctor, A. (2009). Intersections of Race, Class, Gender, and Crime Future Directions for $\begin{array}{llll}\text { Feminist Criminology. Feminist } \quad \text { Criminology, } & 1(1),\end{array}$ https://doi.org/10.1177/1557085105282899

Burke, L. (2003). The Impact of Maternal Depresssion on Familial Releationships. International Review of Psychiatry, 15(3), 243-255. https://doi: 10.1080/0954026031000136866.

Corey, G. (2008). Psikolojik Danısma Kuram ve Uygulamalar. (Çev.).T. Ergene, Ankara: Metis Yayınlar1.

Chesney Lind, M. (2006). Patriarchy, Crime, And Justice Feminist Criminology In An Era of Backlash. Feminist Criminology,1(1): 6-26.

Coyle, A. (2002). Ceraevi Yönetimine Insan Haklar Göz Önüne Alan Bir Yaklaşım. London: Uluslararası Cezaevi Araştırmaları Merkezi.

Daly, K. (1992, 2). Women's Pathways To Felony Court: Feminist Theories of Lawbreaking and Problems of Representation. Southern California Review Of Law and Women's Studies, 2(1), 11 52.

Dolu, O. (2011). Suç Teorileri Teori, Araștrmada ve Uygulama Kriminoloji. Ankra: Seçkin Yayınevi.

Dökmen, Z.Y. (2015). Toplumsal Cinsiyet, Sosyal Psikolojik Açıklamalar. Ankara: Remzi Kitabevi.

England, C. (2007). The Battered Women's Syndrome: A History and Interpretation of the Law of Self-Defense as it Pertains to Battered Women who Kill their Husbands. Vanderbilt Undergraduate Research Journal, 1, 1-12. https://doi.org/10.15695/vurj.v3i0.2762

Eurostat. (2020, 04 24). Prisoners by Age and Sex Number and Rate for The Relevant Sex and Age groups[crim_pris_age]. Eurostat Statistics Explained. Erişim, 15.09.2020. https://ec.europa.eu/eurostat/statistics-explained

Friedman, S. H., \& Resnick, P. (2007). Child Murder by Mothers: Patterns and Prevention. World Psychiatry, 6 (3), 137-141. 
Gürtuna, O. (2009). Cezaevinde Kadın Olmak ve Cezaevinin Kadın Bakış Açısıyla Sosyolojik Değerlendirmesi: Ankara Sincan Kadın Kapalı Cezaevi Örneği. Yüksek lisans tezi, Ankara Üniversitesi Sosyal Bilimler Enstitüsü.

İçli, T.G, Öğün A., \& Özcan, N. (1995). Ailede Kadmna Karşı Şiddet ve Kadın Suçluluğu. Ankara: TC Devlet Bakanlığı Kadının Statüsü ve Sorunları Genel Müdürlüğü Yayınları.

James, S. (2000). African-American and White Female Homicide Offenders: Women Who Kill Intimate Partners Versus Non-Intimate Partners in Chicago Between 1980-1995. Degree of Doctor of Philosophy, Western Michigan University.

Jensen, V. (2001). Why Women Kill. London: Lynne Rienner Publishers, Inc.

Kadın Cinayetlerini Durduracagız Platformu. (2019). Kadın Cinayetlerini Durduracağı Platformu 2019 Raporu. İstanbul: Kadin Cinayetlerini Durduracagiz Platformu.

Kochan, D. (1989). Beyond the Battered Woman Syndrome: An Argument for the Development of New Standards. Hastings Women's Law, 1, 89-115.

Kurshan, N. (1995). Women and Impirosment in the U.S. History and Current Reality.Philadelphia:Monkeywrech press.

Laporte, L., Poulin, B., Marleau, J., Roy, R., \& Webanck, T. (2003). Filicidal Women: Jail or Psychiatric Ward? Can J Psychiatry, 48(2), 94-98.

Lind, M. C. (2006). Patriarchy, Crime, and Justice. Feminist Criminology, 1(1), 6-26.

McMahon, M. (2013). Homicide, Self-Defence and the (Inchoate). Criminal Law Journal, 37, 7998.

Merlo, V., \& Pollok, M. (2006). Women, Law and Social Control. USA: Person Educatíon.

O'Donovan, K. (1991). Defences for Battered Women Who Kill. Journal of Law and Society, 219240.

Ogle, R., \& Jacobs, S. (2002). Self-Defense and Battered Women Who Kill A New Framework. USA: An imprint of greenwood publisihing group.

Owen, B. (1998). In the mix: Struggle and Survival in A Woman's Prison. Albany: State University of New York Press.

Paulson, J., Dauber, S., \& Leifeman, J. (2006). Individual and Combined Effects of Postpartum Depression in Mothers and Fathers on Parenting Behavior. Pediatrics, 118(2), 659-668. https://doi.org/10.1542/peds.2005-2948 
Resnick, P. J. (1969). Child murder by parents: A Psychiatric Review of Filicide. The American Journal of Psychiatry, 126(3), 325-334. https://doi.org/10.1176/ajp.126.3.325

Resnick, S. H. (2007). Child Murder By Mothers: Patterns and Prevention. World Psychiatry, 6(3), $137-141$.

Singh, R. (2008). The Subculture of Violence. A. M. Randy Seepersad (Eds.), The Root Causes of Youth Violence: A Review of Major Theoretical Perspectives. Toronto: Ontoria.

TCK. (2004). Türk Ceza Kanunu Mevzuatı. T.C. Cumhurbaşkanlığı Mevzuat Bilgi Sistemi: Erişim, 10.10.2020. https://www.mevzuat.gov.tr/MevzuatMetin/

Unodc. (2019). Global Study on Homicide Gender-Related Killing of Women and Girls. Vienna: United Nations.

Walker, L.E.A. (2000). The Battered Women Syndrome.2ed Edition, USA: Sipringer Publishing Company.

Wallace, A. (1986). Homicide: The Social Reality. Sydney: New South Wales Bureau of Crime Statistics and Research. 